Криворучко О. П., аспірант (Національний університет водного господарства та природокористування, м. Рівне)

\title{
МОДЕЛЬ ІНВЕСТИЦІЙНОГО ЗАБЕЗПЕЧЕННЯ У ГАЛУЗЬ ТРАНСПОРТУ В УКРАї̈І
}

В статті проаналізовано та визначено, що найбільш ефективний напрям розвитку транспортного сектору України може бути реалізований шляхом формування транспортно-логістичної системи країни, що потребує значних фінансових інвестицій. За допомогою побудови економіко-математичної регресійно лінійної модель взаємозв'язку одних чинників - обсягу інвестицій, на показники розвитку економіки, валовий внутрішній продукт, який характеризує кінцевий результат виробничої діяльності економічних одиницьрезидентів у сфері матеріального і нематеріального виробництва у галузі транспорту, доведено, що інвестиції в транспорт мають: високий рівень ліквідності; короткий термін окупності; доступний інвесторам різного рівня. А зростання обсягу прямих іноземних інвестицій $\epsilon$ необхідною умовою зростання вітчизняної економіки. Ключові слова: регресійно лінійна модель, прямі іноземні інвестиції, методу найменших квадратів, коефіцієнт кореляції, коефіцієнт детермінації.

Постановка проблеми у загальному вигляді. Аналіз світового досвіду свідчить, що найбільш якісні транспортні послуги можуть бути забезпечені через формування транспортно-логістичної системи країни, що потребує значних фінансових інвестицій. Ринок транспорту в усьому світі завжди знаходиться в стадії динамічного зростання і розвитку, в силу затребуваності транспортних засобів. Саме тому інвестиції в транспорт мають: високий рівень ліквідності; короткий термін окупності; доступний інвесторам різного рівня.

Аналіз останніх досліджень і публікацій. Дослідження процесів інвестиційного забезпечення розвитку галузі транспорту знаходиться в центрі уваги багатьох вітчизняних науковців, зокрема таких як: В. Дикань, О. Дикань, Г. Ейтутіс, М. Корінь, В. Овчиннікова, І. Токмакова, О. Ярмоліцька та ін.

Формулювання цілей статті (постановка завдання). Варто відзначити, що в науковій літературі розкрито різнопланові моделі інвестиційного забезпечення у галузь транспорту в Україні. Проте, єди- 
ного підходу до оптимальної моделі інвестиційного забезпечення немає. Метою статті $є$ дослідження залучення прямих іноземних інвестицій для ефективного їх функціонування в галузі транспорту в Україні.

Виклад основного матеріалу. Оцінимо можливий ефект від зростання обсягу залучених інвестицій у галузь транспорту в Україні. Для цього побудуємо економіко-математичну регресійну лінійну модель взаємозв'язку одних чинників - обсягу інвестицій, на показники розвитку економіки, валовий внутрішній продукт, який характеризує кінцевий результат виробничої діяльності економічних одиниць-резидентів у сфері матеріального і нематеріального виробництва у галузі транспорту.

Розглянемо статистичні дані про обсяг інвестицій та ВВП України за видом діяльності «Транспорт, складське господарство, поштова та кур'єрська діяльність за 2012 - 2017 роки (табл. 1).

Таблиця 1

Статистичні дані прямих іноземних інвестицій та валового внутрішнього продукту за видом діяльності «Транспорт, складське господарство, поштова та кур'єрська діяльність»

\begin{tabular}{|c|c|c|}
\hline Роки & $\begin{array}{c}\text { Обсяг прямих іноземних ін- } \\
\text { вестицій, млн. дол. США }\end{array}$ & ВВП, млн. дол. США \\
\hline 2012 & 1427,6 & 12334,2 \\
\hline 2013 & 1535,3 & 13164,0 \\
\hline 2014 & 1355,5 & 8487,5 \\
\hline 2015 & 1088,0 & 6179,0 \\
\hline 2016 & 1086,0 & 6134,5 \\
\hline 2017 & 1164,4 & 7152,4 \\
\hline
\end{tabular}

Джерело: [8]

Побудуємо кореляційне поле між цими показниками (рис. 1). Бачимо, що між індексом обсягом прямих іноземних інвестицій та ВВП може існувати лінійна залежність.

Для побудови і аналізу загальної лінійної економетричної моделі розглянутих даних використаємо апарат матричної алгебри. Для даного економічного процесу вибіркову модель подамо у матричному вигляді: 


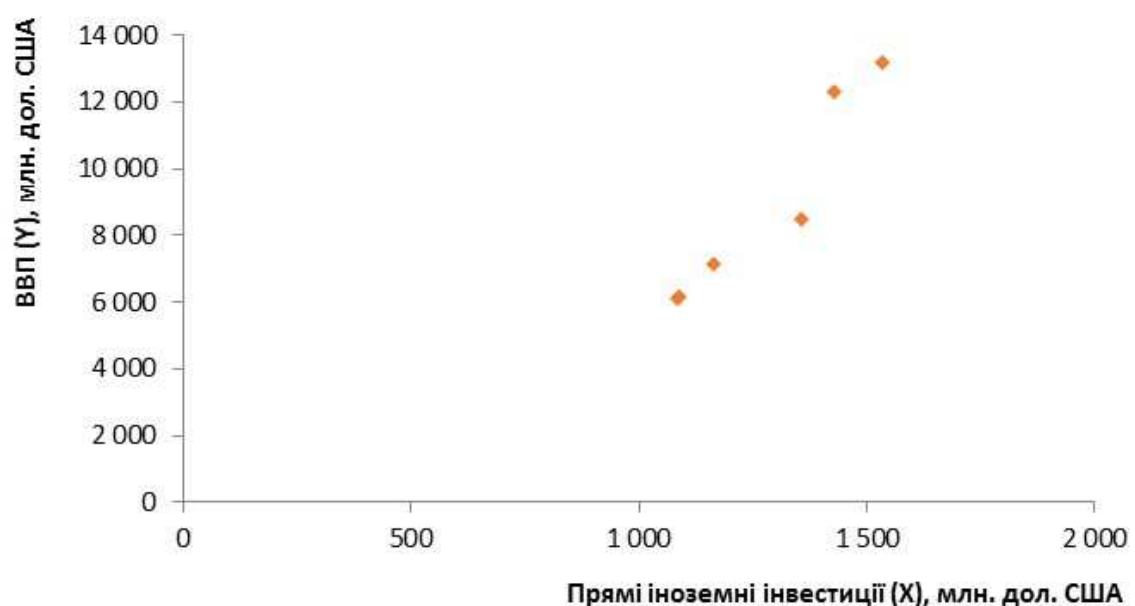

Рис. 1. Кореляційне поле між прямими іноземними інвестиціями та ВВП за видом діяльності «Транспорт, складське господарство, поштова та кур'єрська діяльність» за 2012-2017 роки

$$
\mathrm{Y}=\mathrm{XB}+\mathrm{e},
$$

де $\mathrm{Y}=\left(\begin{array}{c}\mathrm{y}_{1} \\ \mathrm{y}_{2} \\ \ldots \\ \mathrm{y}_{\mathrm{n}}\end{array}\right), \operatorname{dim} \mathrm{Y}=\mathrm{n} \times 1$ - вектор спостережень за залежною змінною моделі ;

$$
\mathrm{X}=\left(\begin{array}{ccccc}
1 & \mathrm{x}_{11} & \mathrm{x}_{21} & \cdots & \mathrm{x}_{\mathrm{m} 1} \\
1 & \mathrm{x}_{12} & \mathrm{x}_{22} & \cdots & \mathrm{x}_{\mathrm{m} 2} \\
\cdots & \cdots & \cdots & \cdots & \cdots \\
1 & \mathrm{x}_{1 \mathrm{n}} & \mathrm{x}_{2 \mathrm{n}} & \cdots & \mathrm{x}_{\mathrm{mn}}
\end{array}\right), \operatorname{dim} \mathrm{X}=\mathrm{n} \times \mathrm{k} \text { - матриця спостере- }
$$

жень за пояснюючими змінними моделі, яку ще називають регресійною матрицею;

$$
\mathrm{B}=\left(\begin{array}{c}
\mathrm{b}_{0} \\
\mathrm{~b}_{1} \\
\mathrm{~b}_{2} \\
\cdots \\
\mathrm{b}_{\mathrm{m}}
\end{array}\right), \operatorname{dim} \mathrm{B}=\mathrm{k} \times 1 \text { - вектор оцінок параметрів моделі (вектор }
$$

параметрів вибіркової моделі) ; 


$$
\mathrm{e}=\left(\begin{array}{c}
\mathrm{e}_{1} \\
\mathrm{e}_{2} \\
\ldots \\
\mathrm{e}_{\mathrm{n}}
\end{array}\right), \operatorname{dim} \mathrm{e}=\mathrm{n} \times 1 \text { - вектор залишків моделі; }
$$

n - розмір статистичної вибірки (кількість спостережень в статистичній вибірці);

m - число незалежних (пояснюючих) змінних моделі;

$\mathrm{k}=\mathrm{m}+1$ - число параметрів моделі.

У випадку двохфакторної моделі маємо:

$$
Y=\left(\begin{array}{ll}
1 & 427,6 \\
1 & 535,3 \\
1 & 355,5 \\
1 & 088,0 \\
1 & 086,0 \\
1 & 164,4
\end{array}\right) \quad X=\left(\begin{array}{rl}
12 & 334,2 \\
13 & 164,0 \\
8 & 487,5 \\
6 & 179,0 \\
6 & 134,5 \\
7 & 152,4
\end{array}\right)
$$

Для оцінювання параметрів вибіркової моделі використовуються різні методи, такі як: метод моментів, метод найменших квадратів, метод максимальної правдоподібності та інші. До найбільш простих і розповсюджених методів відноситься широко відомий метод найменших квадратів, який становить основу регресійного аналізу.

В основу методу найменших квадратів покладено критерій, згідно якого, «найкращою» серед усіх можливих вважається функція регресії з такими параметрами, для якої сума квадратів залишків $\epsilon$ мінімальною. У математичному вигляді цей критерій має наступний вигляд:

$$
\sum_{\mathrm{i}=1}^{\mathrm{n}} \mathrm{e}_{\mathrm{i}}^{2} \rightarrow \min .
$$

Використовуючи цей критерій і визначаються параметри вибіркової лінійної моделі.

Подамо рівняння (3) у вигляді : e $=\mathrm{Y}-\mathrm{XB}$. Тоді суму квадратів залишків е можна записати таким чином :

$$
\sum_{\mathrm{i}=1}^{\mathrm{n}} \mathrm{e}_{\mathrm{i}}^{2}=\mathrm{e}^{\prime} \mathrm{e}=(\mathrm{Y}-\mathrm{XB})^{\prime}(\mathrm{Y}-\mathrm{XB})=\mathrm{Y}^{\prime} \mathrm{Y}-2 \mathrm{~B}^{\prime} \mathrm{X}^{\prime} \mathrm{Y}+\mathrm{B}^{\prime} \mathrm{X}^{\prime} \mathrm{XB} .
$$

Для мінімізації суми квадратів залишків візьмемо похідну від виразу за вектором оцінок параметрів В і прирівняємо похідні до нуля :

$$
\frac{\partial \sum_{i=1}^{n} \mathrm{e}_{\mathrm{i}}^{2}}{\partial \mathrm{B}}=\frac{\partial\left(\mathrm{e}^{\prime} \mathrm{e}\right)}{\partial \mathrm{B}}=-2 \mathrm{X}^{\prime} \mathrm{Y}+2 \mathrm{X}^{\prime} \mathrm{XB}=0 .
$$

Остаточно маємо : 


$$
\mathrm{X}^{\prime} \mathrm{XB}=\mathrm{X}^{\prime} \mathrm{Y} .
$$

Цей вираз представляє собою матричну форму запису системи нормальних рівнянь. Розв'язавши її відносно вектора оцінок В отримаємо оцінку параметрів моделі. 3 цією метою помножимо обидві частини виразу на обернену матрицю $\left(\mathrm{X}^{\prime} \mathrm{X}\right)^{-1}$ та отримаємо:

$$
\mathrm{B}=\left(\mathrm{X}^{\prime} \mathrm{X}\right)^{-1} \mathrm{X}^{\prime} \mathrm{Y} \text {. }
$$

Таким чином, сформувавши на основі статистичної вибірки вектор спостережень за залежною змінною моделі Ү і матрицю спостережень за незалежними змінними моделі X, за формулою (6) можна обчислити вектор оцінок параметрів моделі В.

Для зручності використання формули (6) розпишемо у розгорнутій формі матриці $\left(\mathrm{X}^{\prime} \mathrm{X}\right)$ та $\mathrm{X}^{\prime} \mathrm{Y}$ :

$$
\left(X^{\prime} X\right)=\left(\begin{array}{ccccc}
n & \sum_{i=1}^{n} x_{1 i} & \sum_{i=1}^{n} x_{2 i} & \cdots & \sum_{i=1}^{n} x_{m i} \\
\sum_{i=1}^{n} x_{1 i} & \sum_{i=1}^{n} x_{1 i}^{2} & \sum_{i=1}^{n} x_{1 i} x_{2 i} & \cdots & \sum_{i=1}^{n} x_{1 i} x_{m i} \\
\sum_{i=1}^{n} x_{2 i} & \sum_{i=1}^{n} x_{2 i} x_{1 i} & \sum_{i=1}^{n} x_{2 i}^{2} & \cdots & \sum_{i=1}^{n} x_{2 i} x_{m i} \\
\cdots & \cdots & \cdots & \cdots & \cdots \\
\sum_{i=1}^{n} x_{m i} & \sum_{i=1}^{n} x_{m i} x_{1 i} & \sum_{i=1}^{n} x_{m i} x_{2 i} & \cdots & \sum_{i=1}^{n} x_{m i}^{2}
\end{array}\right),
$$

$\operatorname{dim}\left(\mathrm{X}^{\prime} \mathrm{X}\right)=\mathrm{k} \times \mathrm{k}$.

$$
X^{\prime} Y=\left(\begin{array}{c}
\sum_{i=1}^{n} y_{i} \\
\sum_{i=1}^{n} y_{i} x_{1 i} \\
\sum_{i=1}^{n} y_{i} x_{2 i} \\
\cdots \\
\sum_{i=1}^{n} y_{i} x_{m i}
\end{array}\right), \operatorname{dim} X^{\prime} Y=k \times 1 \text {. }
$$

Обчислимо потрібні значення сум в табл. 2. В результаті отримаємо:

$$
B=\left(\begin{array}{ll}
6 & 1276,1 \\
1276,1 & 9951535,5
\end{array}\right)^{-1}\left(\begin{array}{l}
53451,6 \\
71036951,1
\end{array}\right)=\left(\begin{array}{l}
-11074,8 \\
15,7
\end{array}\right)
$$

Підставимо отримані результати в економетричну модель та отримаємо наступну формулу залежності ВВП від індексу інвестиційної привабливості: 


$$
Y=15,7^{*} X-11074,8
$$

де $Y$ - ВВП, $X$ - обсяг прямих іноземних інвестицій.

Дану модель потрібно верифікувати з допомогою показників якості моделі та перевірити їх статистичну значущість. До основних показників якості побудованої вибіркової моделі відносяться наступні показники:

- коефіцієнт кореляції;

- коефіцієнт детермінації.

Коефіцієнт кореляції $є$ кількісною мірою тісноти лінійного кореляційного зв'язку між змінними моделі і у загальному випадку представляє собою коефіцієнт множинної кореляції, який обчислюється за наступною залежністю:

$$
R=\frac{\sum_{i=1}^{n}\left(y_{i}-\bar{y}\right)\left(\hat{y}_{i}-\overline{\bar{y}}\right)}{\sqrt{\sum_{i=1}^{n}\left(y_{i}-\bar{y}\right)^{2}} \sqrt{\sum_{i=1}^{n}\left(\hat{y}_{i}-\bar{y}\right)^{2}}},
$$

де $\mathrm{y}_{\mathrm{i}}$ - фактичні (статистичні) значення залежної змінної, $\widehat{\mathrm{y}}_{\mathrm{i}}-$ розрахункові значення.

У випадку парної лінійної регресії щільність лінійного кореляційного зв'язку між залежною змінною у і незалежною змінною $\mathrm{x}$ оцінюється за допомогою відомого коефіцієнта парної кореляції:

$$
\mathrm{r}_{\mathrm{yx}}=\frac{\operatorname{cov}(\mathrm{x}, \mathrm{y})}{\sqrt{\operatorname{var}(\mathrm{x})} \sqrt{\operatorname{var}(\mathrm{y})}},
$$

де $\operatorname{cov}(\mathrm{x}, \mathrm{y})=\frac{1}{\mathrm{n}} \sum_{\mathrm{i}=1}^{\mathrm{n}}\left(\mathrm{x}_{\mathrm{i}}-\overline{\mathrm{x}}\right)\left(\mathrm{y}_{\mathrm{i}}-\overline{\mathrm{y}}\right)-$ вибірковий коефіцієнт коваріації, $\operatorname{var}(\mathrm{x})=\frac{1}{\mathrm{n}} \sum_{\mathrm{i}=1}^{\mathrm{n}}\left(\mathrm{x}_{\mathrm{i}}-\overline{\mathrm{x}}\right)^{2}$ - вибіркова дисперсія пояснюючої змінної моделі, $\operatorname{var}(\mathrm{y})=\frac{1}{\mathrm{n}} \sum_{\mathrm{i}=1}^{\mathrm{n}}\left(\mathrm{y}_{\mathrm{i}}-\overline{\mathrm{y}}\right)^{2}-$ вибіркова дисперсія залежної змінної моделі.

Коефіцієнт детермінації використовується як критерій адекватності (відповідності) моделі статистичним даним, оскільки він $є$ мірою пояснювальної сили незалежних змінних і показує, яка частина варіації залежної змінної пояснюється саме варіацією (зміною) незалежних змінних, а не іншими випадковими факторами, які акумулюються у стохастичній складовій моделі. Іншими словами, коефіцієнт детермінації показує наскільки значним $є$ вплив пояснюючих змінних моделі на залежну. 
Таблиця 2

Розрахунок статистичних даних для визначення параметрів моделі

\begin{tabular}{|c|c|c|c|c|c|c|c|c|c|}
\hline Роки & $x_{i}$ & $y_{i}$ & $x_{i}^{2}$ & $x_{i} y_{i}$ & $x_{i}-\bar{x}$ & $y_{i}-\bar{y}$ & $\begin{array}{c}\left(x_{i}-\bar{x}\right)^{*} \\
\left(y_{i}-\bar{y}\right)\end{array}$ & $\left(x_{i}-\bar{x}\right)^{2}$ & $\left(y_{i}-\bar{y}\right)^{2}$ \\
\hline 2012 & 1427,6 & 12334,2 & 2038041,8 & 17608319,3 & 151,5 & 3425,6 & 518864,8 & 22942,2 & 11734762,8 \\
\hline 2013 & 1535,3 & 13164,0 & 2357146,1 & 20210759,9 & 259,2 & 4255,4 & 1102868,0 & 67167,4 & 18108763,7 \\
\hline 2014 & 1355,5 & 8487,5 & 1837380,3 & 11504867,5 & 79,4 & $-421,1$ & $-33418,3$ & 6299,1 & 177292,9 \\
\hline 2015 & 1088,0 & 6179,0 & 1183744,0 & 6722730,3 & $-188,1$ & $-2729,6$ & 513533,8 & 35394,2 & 7450862,1 \\
\hline 2016 & 1086,0 & 6134,5 & 1179396,0 & 6662056,1 & $-190,1$ & $-2774,1$ & 527452,1 & 36150,7 & 7695723,8 \\
\hline 2017 & 1164,4 & 7152,4 & 1355827,4 & 8328218,0 & $-111,7$ & $-1756,2$ & 196230,3 & 12484,3 & 3084372,6 \\
\hline Суми & 7656,8 & 53451,6 & 9951535,5 & 71036951,1 & 0,0 & 0,0 & 2825530,8 & 180437,8 & 48251777,9 \\
\hline Середні & 1276,1 & 8908,6 & & & & & & & \\
\hline
\end{tabular}


Якщо цей вплив $є$ значним, то побудована модель дійсно описує лінійну залежність між відповідними економічними показниками і ця залежність $€$ суттєвою. Якщо ж цей вплив $\epsilon$ незначним модель $\epsilon$ неадекватною статистичним даним і лінійна регресійна залежність між економічними показниками у ній $є$ достатньо сумнівною і неякісною.

Позначається коефіцієнт детермінації через $\mathrm{R}^{2} \mathrm{i}$ обчислюється за наступною залежністю:

$$
\mathrm{R}^{2}=1-\frac{\sum_{\mathrm{i}=1}^{\mathrm{n}} \mathrm{e}_{\mathrm{i}}^{2}}{\sum_{\mathrm{i}=1}^{\mathrm{n}}\left(\mathrm{y}_{\mathrm{i}}-\overline{\mathrm{y}}\right)^{2}} .
$$

Зазначимо також, що коефіцієнт детермінації може обчислюватися і за іншими формулами. Так у математичній статистиці доведено, що коефіцієнт детермінації і коефіцієнт множинної (парної) кореляції пов'язані наступним співвідношенням:

$$
\begin{gathered}
\mathrm{R}^{2}=(\mathrm{R})^{2} \text { (для множинної регресії), } \\
\mathrm{R}^{2}=\left(\mathrm{r}_{\mathrm{yx}}\right)^{2} \text { (для парної регресіi). }
\end{gathered}
$$

Таким чином у практичних розрахунках достатньо обчислити тільки коефіцієнт кореляції.

Чим більше значення коефіцієнта детермінації (чим ближче воно до 1) тим більш вагомим і систематичним $є$ вплив пояснюючих змінних на залежну і тим більше підстав стверджувати, що саме зміною значень пояснюючих змінних пояснюється змінна значення залежної змінної моделі, а не іншими випадковими і неврахованими у моделі випадковими факторами. Іншими словами високе, близьке до 1 значення коефіцієнта детермінації свідчить про високий рівень адекватності оціненої моделі статистичним даним.

За даними табл. 3 обчислимо коефіцієнт кореляції:

$$
\begin{aligned}
& r_{y x}=\frac{\operatorname{cov}(x, y)}{\sqrt{\operatorname{var}(x) \sqrt{\operatorname{var}(y)}}} \\
& r_{y x}=\frac{2825530,8}{\sqrt{180437,8 * 48251777,9}}=0,958 .
\end{aligned}
$$

Коефіцієнт детермінації: $\mathrm{R}^{2}=0,917$. Тобто, 8,3\% зміни значень показника (ВВП) пояснюється випадковими чинниками. Згідно зі шкалою Чеддока [9], взаємозв'язок між досліджуваними факторами, який характеризується коефіцієнтом кореляції, є сильним.

Регресійна модель, а точніше рівняння регресії, можна вважати статистично значимим («вірним»), якщо воно дійсно відображує лінійну залежність між економічними показниками у цьому рівнянні. 
Це можливо, якщо коефіцієнт детермінації $\mathrm{R}^{2} \epsilon$ достатньо близьким до одиниці. Якщо ж він дорівнює нулю або несуттєво відрізняється від нуля залежність між змінними моделі відсутня і отримане вибіркове рівняння регресії не відтворює реальної ситуації.

Таким чином перевірка статистичної значимості моделі у цілому зводиться до перевірки статистичної значимості коефіцієнта детермінації, тобто перевірки того, чи суттєво його реальне значення відрізняється від нуля.

3 цією метою висуваються наступні дві гіпотези:

$$
\begin{aligned}
& \mathrm{H}_{0}: \mathrm{R}^{2}=0, \\
& \mathrm{H}_{1}: \mathrm{R}^{2} \neq 0 .
\end{aligned}
$$

Перша, нульова гіпотеза стверджує, що оцінене вибіркове рівняння регресії не пояснює зміну залежної змінної під впливом пояснюючих змінних. Друга, альтернативна гіпотеза навпаки стверджує, що варіація залежною зміною пояснюється впливом пояснюючих змінних.

Для перевірки гіпотез використовується наступна F - статистика (F - критерій Фішера) :

$$
\mathrm{F}=\frac{\mathrm{R}^{2}}{1-\mathrm{R}^{2}} \cdot \frac{\mathrm{n}-\mathrm{k}}{\mathrm{m}}
$$

яка, якщо нуль-гіпотеза $є$ вірною, має розподіл Фішера із ступенями вільності $v_{1}=\mathrm{m}$ i $v_{2}=\mathrm{n}-\mathrm{k}$. Перевірку статистичної значимості моделі у цілому здійснимо наступним чином .

1. На основі значення вибіркового коефіцієнта детермінації $\mathrm{R}^{2}$ обчислюється розрахункове значення критерію Фішера $\mathrm{F}^{*}$ :

$$
\mathrm{F}^{*}=\frac{0,917}{1-0,917} * \frac{6-2}{1}=44,8
$$

2. Задаємо рівень значимості $\alpha=0,05$.

3. За статистичними таблицями критичних точок F-розподілу Фішера-Снедекора для прийнятого рівня значимості $\alpha$ і ступенів вільності $k_{1}=m=1$ i $k_{2}=n-k=4$ визначається критичне (табличне) значення критерію Фішера $\mathrm{F}_{\mathrm{kp}}=6,6$ [9].

4. Так, як виконується умова $\mathrm{F}^{*}>\mathrm{F}_{\text {кр }}$, то нульова гіпотеза відкидається на користь альтернативної, що свідчить про статистичну значимість побудованої моделі у цілому і її адекватність.

Отже, приведена модель $є$ адекватною, і вірно описує залежність між обсягом прямих іноземних інвестицій та ВВП за видом діяльності «Транспорт, складське господарство, поштова та кур'єрська діяльність». Зобразимо графічно отримані результати моделювання (рис. 2). 


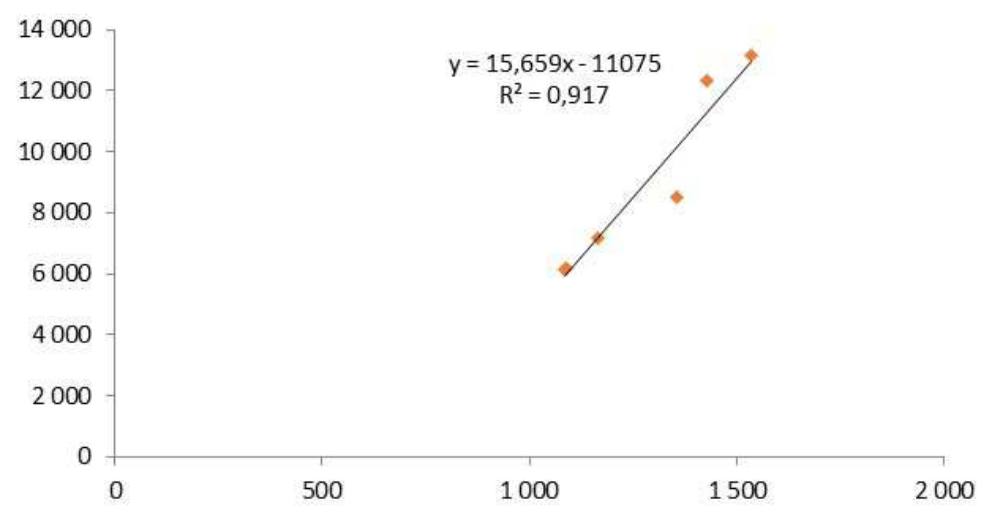

Рис. 2. Модель залежності між обсягом прямих іноземних інвестицій та ВВП за видом діяльності «Транспорт, складське господарство, поштова та кур'єрська діяльність»

Отримана економіко-математична регресійна лінійна модель дозволяє визначити прогнозоване значення залежної змінної (ВВП) шляхом підстановки в рівняння відповідного значення незалежної змінної (прямих інвестицій).

Визначимо прогнозне ВВП за видом діяльності «Транспорт, складське господарство, поштова та кур'єрська діяльність» при 10\% рості обсягу прямих інвестицій (відносно рівня 2017 року, + 194,8 млн дол. США; 1054,0 * 10\%) за визначеною моделлю:

$\mathrm{Y}_{\text {пр }}=1280,8 * 15,7-11074,8=8982$ млн дол. США, що на 25,6\% більше обсягу ВВП за видом діяльності «Транспорт, складське господарство, поштова та кур'єрська діяльність» у 2017 році (рис. 3).

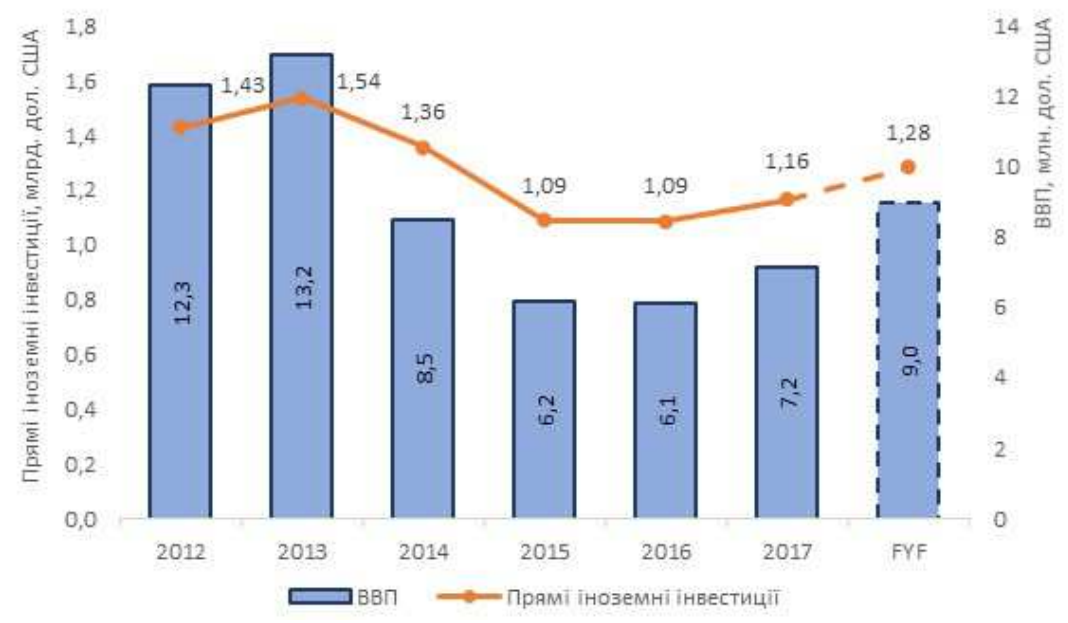

Рис. 3. Прогнозне значення ВВП за видом діяльності «Транспорт, складське господарство, поштова та кур'єрська діяльність» за обсягом прямих іноземних інвестицій 
Прогнозний ріст ВВП України при $10 \%$ рості прямих інвестицій за видом діяльності «Транспорт, складське господарство, поштова та кур'єрська діяльність» становитиме: 1,6\% (6,4\%, частка ВВП за видом діяльності «Транспорт, складське господарство, поштова та кур'єрська діяльність» у 2017 у загальному обсязі ВВП України, * 25,6\%). Зростання обсягу прямих іноземних інвестицій $€$ необхідною умовою зростання вітчизняної економіки.

Висновки із цього дослідження. Отже, залучення прямих іноземних інвестицій дає прямі й непрямі вигоди й переваги для національної економіки: збільшення ресурсів для відновлення й розширення основного капіталу, реалізації інвестиційних програм та проектів, що забезпечує прискорений розвиток економіки; впровадження нових технологій та процесів, що призводить до зростання рівня конкурентоспроможності як суб'єктів господарювання так і товарів, послуг; підвищення кваліфікації персоналу; прискорює процес формування в країні інвестиційного клімату, сприятливого, як для вітчизняних, так і зарубіжних інвесторів; розвиток ефективних інтеграційних процесів, прискорення інтеграції вітчизняної економіки в світову економіку, використання переваг міжнародного поділу і кооперації.

1. Угода про позику (Проект розвитку дорожньої галузі) між Україною та Міжнародним банком реконструкції та розвитку від 19 листопада 2015 р. URL: http://zakon.rada.gov.ua/laws/show/996_076 (дата звернення: 15.01.2019). 2. Шиба О. А. Стратегія розвитку транспортної інфраструктури України в умовах євроінтеграції. Причорноморські економічні студії. 2016. Вип. 8. С. 35-40. URL: http://nbuv.gov.ua/UJRN/bses_2016_8_9 (дата звернення: 15.01.2019). 3. Інфраструктурне забезпечення розвитку транспортної системи регіону : колективна монографія. / І. В. Заблодська, І. Р. Бузько, О. О. Зеленко, І. О. Хорошилова. Сєвєродонецьк : Вид-во СНУ ім. В. Даля, 2016. 193 с. 4. Савіна Н. Концептуальні засади інвестиційної логістики. Економічний вісник НТУУ «КПІ» : зб. наук. праць. 2011. Вип. 8. С. 300-305. 5. Брагінський В. В. Розвиток транспортно-логістичної системи як форма реалізації транзитного потенціалу України. URL: http://academy.gov.ua/ej/ej14/txts/Braginskiy.pdf (дата звернення: 15.01.2019). 6. Розвиток транспортної мережі в Україні / MIY. URL: http://www.traceca org.org/fileadmin/fm dam/Investment_Forum/3_TEN T_e xtension_Ukraine_eng.pdf (дата звернення: 15.01.2019). 7. Міністерство інфраструктури України. Мережа міжнародних транспортних коридорів на території України. URL: http://www.mtu.gov.ua/uk/ show/transports.htm (дата звернення: 15.01.2019). 8. Офіційний сайт Національного інституту стратегічних досліджень при Президенті України URL: http://www.niss.gov.ua. (дата звернення: 15.01.2019). 9. Хорошилова І. О., Васильчук Н. О. Якісна інфраструктура транспортної системи Харківського регіону, як необхідна 
умова розвитку України. Становлення сучасного українського суспільства: політичні, управлінські, економічні та правові аспекти : всеукр. наук.-практ. конф., 27 берез. 2015 р.: тези доповід. К. : Центр КНУКіМ. 2015. С. 65-68. 10. Никифорук О. І., Чмирьова Л. Ю. Зміна моделі фінансування дорожньої інфраструктури в Україні. Економіка і прогнозування. 2014. № 4. С. 38-56. URL: http://nbuv.gov.ua/UJRN/econprog_2014_4_5 (дата звернення: 15.01.2019). 11. Орленко Я. Ю. Вдосконалення державного регулювання інвестиційних процесів у аграрному секторі економіки. URL: http://www.economy.in.ua/pdf/11_2012/38.pdf (дата звернення: 15.01.2019). 12. Коденська М. Ю. Інтеграція як фактор активізації інвестиційної діяльності. Економіка АПК. 2006. № 6. С. 24-31. 13. Інформаційний бюлетень Міжнародного центру перспективних досліджень : Постанова № 139, від 11 лютого 2002 року. Вісник центру Модернізація транспорту сприятиме розвитку економіки. URL: http://zakon.rada.gov.ua/laws/show/139-2002\%D0\%BF (дата звернення: 15.01.2019). 14. Біліченко В. В. Передумови обґрунтування стратегічного розвитку виробничих систем автомобільного транспорту в Україні. Вісник ЖДТУ. 2014. № 2 (69). С. 33-42. 15. Тройнікова О. М. Підходи до управління безпекою транспортних процесів на залізниці. Энергосбережение. Энергетика. Энергоаудит. Вип. № 1 (132). 2015 р. С. 54-60. 16. Державна політика транспортної безпеки України: актуальні питання реалізації. URL: http://veche.kiev.ua/journal/1866/ (дата звернення: 15.01.2019). 17. Маловичко А. Експорт транспортних послуг у міжнародній і зовнішній торгівлі. Донецький національний університет економіки й торгівлі імені Михайла Туган-Барановського. 18. Замлинський В. А. Стан та перспективи розвитку експортного потенціалу ринку послуг автомобільного транспорту.

URL:

http://www.economyandsociety.in.ua/journal/9_ukr/36.pdf (дата звернення: 15.01.2019). 19. Каличева Н. Є. Стецюк М. І. Удосконалення системи управління персоналом в умовах розвитку підприємства. Вісник економіки транспорту і промисловості. 2015. Вип. 49. С. 195-198. 20. Дикань В. Л. Перспективы развития экономики Украины в условиях формирования международных транспортных коридоров в системе мировой глобализации экономики. Вісник економіки транспорту і промисловості : зб. наук.-практичних статей. Харків : УкрДАЗТ, 2013. Вип. 42. С. 144-149. 21. Каличева Н. Є., Маслова В. О. Логістичні підходи, як основа раціональної організації виробничого процесу на підприємстві. Вісник економіки транспорту і промисловості : зб. наук.-практичних статей. Харків : УкрДАЗТ, 2014. № 47. С. 83-86. 22. Концепція формування сталої національної транспортної політики розвитку всіх видів транспорту та засад (стратегіï) транспортної політики. URL: http://zt.knteu.kiev.ua/files/2017/02(91)/07.pdf (дата звернення: 15.01.2019). 23. Національна транспортна стратегія України на період до 2030 року. URL: http://zakon.rada.gov.ua/laws/show/430-2018-\%D1\%80 (дата звернення: 15.01.2019). 24. Транспортна стратегія України на період до 2020 року. URL: $\quad$ https://www.kmu.gov.ua/ua/npas/pro-shvalennya-nacionalnoyitransportnoyi-strategiyi-ukrayini-na-period-do-2030-roku (дата звернення: 15.01.2019). 25. Концепція розвитку транспортно-дорожнього комплексу 
(ТДК) України до 2015 року і подальший період. URL: http://www.uchika.in.ua/koncepciya-rozvitku-transportno-dorojneogokompleksu-tdk-ukray.html (дата звернення: 15.01.2019).

\section{REFERENCES:}

1. Uhoda pro pozyku (Proekt rozvytku dorozhnoi haluzi) mizh Ukrainoiu ta Mizhnarodnym bankom rekonstruktsii ta rozvytku vid 19 lystopada 2015 r. URL: http://zakon.rada.gov.ua/laws/show/996_076 (data zvernennia: 15.01.2019). 2. Shyba 0. A. Stratehiia rozvytku transportnoi infrastruktury Ukrainy $v$ umovakh yevrointehratsii. Prychornomorski ekonomichni studii. 2016. Vyp. 8. S. 35-40. URL: http://nbuv.gov.ua/UJRN/bses_2016_8_9 (data zver-nennia: 15.01.2019). 3. Infrastrukturne zabezpechennia rozvytku transportnoi systemy rehionu : kolektyvna monohrafiia / I. V. Zablodska, I. R. Buzko, 0. O. Zelenko, I. O. Khoroshylova. Sievierodonetsk. Vyd-vo SNU im. V. Dalia, 2016. 193 s. 4. Savina N. Kontseptualni zasady investytsiinoi lohistyky. Ekonomichnyi visnyk NTUU «KPI»: zb. nauk. prats. 2011. Vyp. 8. S. 300-305. 5. Brahinskyi V. V. Rozvytok transportno-lohistychnoi systemy yak forma realizatsii tranzytnoho potentsialu Ukrainy. URL: http://academy.gov.ua/ej/ej14/txts/Braginskiy.pdf (data zvernennia: 15.01.2019). 6. Rozvytok transportnoi merezhi v Ukraini / MIU. URL: http://www.traceca org.org/fileadmin/fm dam/Investment_Forum/3_TEN T_extension_Ukraine_eng.pdf (data zvernennia: 15.01.2019). 7. Ministerstvo infrastruktury Ukrainy. Merezha mizhnarodnykh transportnykh korydoriv na terytorii Ukrainy. URL: http://www.mtu.gov.ua/uk/ show/transports.htm (data zvernennia: 15.01.2019). 8. Ofitsiinyi sait Natsionalnoho instytutu stratehichnykh doslidzhen pry Prezydenti Ukrainy. URL: http://www.niss.gov.ua. (data zvernennia: 15.01.2019). 9. Khoroshylova I. 0., Vasylchuk N. 0. Yakisna infrastruktura transportnoi systemy Kharkivskoho rehionu, yak neobkhidna umova rozvytku Ukrainy. Stanovlennia suchasnoho ukrainskoho suspilstva: politychni, upravlinski, ekonomichni ta pravovi aspekty: vseukr. nauk.-prakt. konf., 27 berez. 2015 r.: tezy dopovid. K. : Tsentr KNUKiM. 2015. S. 65-68. 10. Nykyforuk 0. I., Chmyrova L. Yu. Zmina modeli finansuvannia dorozhnoi infrastruktury v Ukraini. Ekonomika i prohnozuvannia. 2014. № 4. S. 38-56. URL: http://nbuv.gov.ua/UJRN/econprog_2014_4_5 (data zvernennia: 15.01.2019). 11. Orlenko Ya. Yu. Vdoskonalennia derzhavnoho rehuliuvannia investytsiinykh protsesiv u ahrarnomu sektori ekonomiky. URL: http://www.economy.in.ua/pdf/11_2012/38.pdf (data zvernennia: 15.01.2019). 12. Kodenska M. Yu. Intehratsiia yak faktor aktyvizatsii investytsiinoi diialnosti. Ekonomika APK. 2006. № 6. S. 24-31. 13. Informatsiinyi biuleten Mizhnarodnoho tsentru perspektyvnykh doslidzhen : Postanova № 139, vid 11 liutoho 2002 roku. Visnyk tsentru Modernizatsiia transportu spryiatyme rozvytku ekonomiky. URL: http://zakon.rada.gov.ua/laws/show/139-2002-\%D0\%BF (data zvernennia: 15.01.2019). 14. Bilichenko V. V. Peredumovy obgruntuvannia stratehichnoho rozvytku vyrobnychykh system avtomobilnoho 
transportu v Ukraini. Visnyk ZhDTU. 2014. № 2 (69). S. 33-42. 15. Troinikova O. M. Pidkhody do upravlinnia bezpekoiu transportnykh protsesiv na zaliznytsi. Enerhosberezhenie. Enerhetika. Enerhoaudit. Vyp. № 1 (132). 2015 r. S. 54-60. 16. Derzhavna polityka transportnoi bezpeky Ukrainy: aktualni pytannia realizatsii. URL: http://veche.kiev.ua/journal/1866/ (data zvernennia: 15.01.2019). 17. Malovychko A. Eksport transportnykh posluh u mizhnarodnii i zovnishnii torhivli. Donetskyi natsionalnyi universytet ekonomiky y torhivli imeni Mykhaila Tuhan-Baranovskoho. 18. Zamlynskyi V. A. Stan ta perspektyvy rozvytku eksportnoho potentsialu rynku posluh avtomobilnoho transportu. URL: http://www.economyandsociety.in.ua/journal/9_ukr/36.pdf (data zvernennia: 15.01.2019). 19. Kalycheva N. Ye. Stetsiuk M. I. Udoskonalennia systemy upravlinnia personalom $v$ umovakh rozvytku pidpryiemstva. Visnyk ekonomiky transportu i promyslovosti. 2015. Vyp. 49. S. 195-198. 20. Dykan V. L. Perspektivy razvitiia ekonomiki Ukrainy $v$ usloviiakh formirovaniia mezhdunarodnykh transportnykh koridorov $v$ sisteme mirovoi hlobalizatsii ekonomiki. Visnyk ekonomiky transportu i promyslovosti : zb. nauk.-praktychnykh statei. Kharkiv : UkrDAZT, 2013. Vyp. 42. S. 144-149. 21. Kalycheva N. Ye., Maslova V. 0. Lohistychni pidkhody, yak osnova ratsionalnoi orhanizatsii vyrobnychoho protsesu na pidpryiemstvi. Visnyk ekonomiky transportu i promyslovosti : zb. nauk.-praktychnykh statei. Kharkiv : UkrDAZT, 2014. № 47. S. 83-86. 22. Kontseptsiia formuvannia staloi natsionalnoi transportnoi polityky rozvytku vsikh vydiv transportu ta zasad (stratehii) transportnoi polityky. URL: http://zt.knteu.kiev.ua/files/2017/02(91)/07.pdf (data zvernennia: 15.01.2019).

23. Natsionalna transportna stratehiia Ukrainy na period do 2030 roku. URL: http://zakon.rada.gov.ua/laws/show/430-2018-\%D1\%80 (data zvernennia: 15.01.2019). 24. Transportna stratehiia Ukrainy na period do 2020 roku. URL: https://www.kmu.gov.ua/ua/npas/pro-shvalennya-nacionalnoyitransportnoyi-strategiyi-ukrayini-na-period-do-2030-roku (data zvernennia: 15.01.2019). 25. Kontseptsiia rozvytku transportno-dorozhnoho kompleksu (TDK) Ukrainy do 2015 roku i podalshyi period. URL: http://www.uchika.in.ua/koncepciya-rozvitku-transportno-dorojneogokompleksu-tdk-ukray.html (data zvernennia: 15.01.2019).

Рецензент: д.е.н., професор Безтелесна Л. І. (НУВГП)

Kryvoruchko 0. P., Post-graduate Student (National University of Water and Environmental Engineering, Rivne)

\section{MODEL OF INVESTMENT PROPERTY IN THE AREA OF TRANSPORT IN UKRAINE}

The article studies and determines the issue, that the most efficient direction of the Ukrainian transport sector development can be realized by forming the transport-logistic system of the country, 
which requires a significant financial investment. Various models of investment support in the field of transport in Ukraine are disclosed in the scientific literature.

But there is no single approach to the optimal model of investment support. The purpose of the article is to study the attraction of foreign direct investment for their efficient functioning in the field of transport in Ukraine.

By building the economic-mathematical linear regression model of interrelation between some factors - amount of investment on indicators of economic development, gross domestic product, which characterizes the final result of the production activities the resident economic units of tangible and intangible production in the transport sector, it has been found out that investment in transport has a high level of liquidity; short payback period; affordable to the different types of investors. Increasing of the foreign direct investment is the essential requirement for the domestic economy growth.

It is proved in the article that investments in transport have: a high level of liquidity; short payback period; available to investors of different levels. Forecast growth of Ukraine's GDP at $10 \%$ growth in direct investment by type of activity "Transport, warehousing, postal and courier activity" will be: $1.6 \%$ (6.4\%, share of GDP by type of activity "Transport, warehousing, postal and courier activity "in 2017 in the total volume of GDP of Ukraine, $25.6 \%$ ). The growth of foreign direct investment is a prerequisite for the growth of the domestic economy.

Consequently, attraction of foreign direct investment gives direct and indirect benefits and advantages to the national economy: increase of resources for restoration and expansion of fixed capital, implementation of investment programs and projects, which provides accelerated economic development; introduction of new technologies and processes, which leads to an increase in the level of competitiveness of both economic entities and goods and services; staff qualification upgrading; accelerates the process of forming an investment climate in the country, favorable for both domestic and foreign investors; the development of effective integration processes, accelerating the integration of the domestic economy into the world economy, the use of the benefits of international division and cooperation.

Keywords: regression linear model, direct foreign investment, least squares method, correlation coefficient, determination coefficient. 
Криворучко О. П., аспирант (Национальный университет водного хозяйства и природопользования, г. Ровно)

\section{МОДЕЛЬ ИНВЕСТИЦИОННОГО ОБЕСПЕЧЕНИЯ В ОБЛАСТИ TРАНСПОРТА В УКРАИНЕ}

В статье проанализированы и определено, что наиболее эффективное направление развития транспортного сектора Украины может быть реализован путем формирования транспортно-логистической системы страны, что требует значительных финансовых инвестиций. С помощью построения экономико-математической регрессионно линейной модели взаимосвязи одних факторов -о объема инвестиций, на показатели развития экономики, валовой внутренний продукт, характеризующий конечный результат производственной деятельности экономических единиц-резидентов в сфере материального и нематериального производства в области транспорта, доказано, что инвестиции в транспорт имеют: высокий уровень ликвидности; короткий срок окупаемости; доступен инвесторам разного уровня. А рост объема прямых иностранных инвестиций является необходимым условием роста отечественной экономики.

Ключевые слова: регрессионно линейная модель, прямые иностранные инвестиции, метода наименьших квадратов, коэффициент корреляции, коэффициент детерминации. 